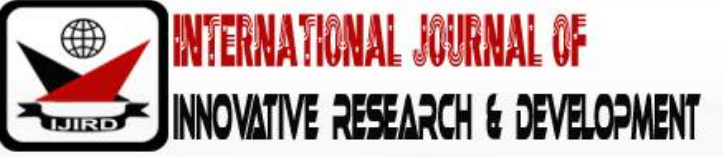

ISSN 2278-0211 (Online)

\section{A Theoretical Analysis of the Divergence Factors That Affect Students Academic Performance in University of Jos, Nigeria}

\begin{tabular}{c} 
Yusuf, Izang Elijah \\
Lecturer, Department of History and International Studies, \\
University of Jos, Nigeria \\
Audu, Garba Tanko \\
Principal Lecturer, Department of History, \\
Taraba State College of Education, Nigeria \\
Yusuf, Izang Fatima \\
Student, Department of Educational Foundation-Guidance and Counselling Unit, \\
University of Jos, Nigeria \\
\hline
\end{tabular}

\begin{abstract}
:
The paper examines theoretically the direct factors influencing academic failure among students in university of Jos, Jos Nigeria. The paper adopted the behaviour modification theory (social learning theory, theory of reasoned action and theory of planned behaviour) from social psychologies to bring to fore the systematic approach to the understanding of the changing nature of human behaviour in a given environment and at a given time and period. The main objective of this paper is to bring to light the salient but known fact on the factors that hinders' students from attaining academic success. The findings reveal that social media, campus prostitution, cultism, social activities, substance abuse and laziness, are the factors affecting academic failure of Students in University of Jos. Key Informant Interview (KII) and Focus Group Discussion were adopted as a major source of primary data, while secondary sources of data collection and participant observation were also adopted. The paper recommends that the Examination Malpractice Act 33 of 1999, be amended to incorporate that section of Degree 20 of 1984 which stated 21 years imprisonment without option of fine for any students caught in the act. This would help reduce, if not eliminate social ills and propel students to study hard.
\end{abstract}

Keywords: Education, academic, student, university, social ill

\section{Introduction}

Poor academic performance is a serious concern not only to University of Jos, but the entire Nigeria's Universities and abroad. The importance of education to the individual and to the nation cannot be overlooked, because education is the bedrock of national growth and development. It is unfortunate, that the level, quality and standard of education in Nigeria have drop drastically and it's still dropping by the day, because students do not have time for studies. They only read during examination period to pass. To gain knowledge is out of the question. Their minds are preoccupied on how to fit in, with reference groups in order to feel accepted in the preconceived social environment. Negative socialization affects students' performance, the educational institutions and the entire country as a whole. The process of socialization in campus (University of Jos), give rise to numerous social vices such as cultism, campus prostitution, substance abuse, abusive relationship, clubbing and partying, social networking examination malpractice etc. These social ills have a lasting and a devastating effect on the academic performance of students, because social vices are usually connected or associated with grades. Most often students result in examination malpractice as their last resolve to pass exams, because time wasted, chasing un-academic activities have hinders' them from preparing for examination.

It is within this perspective that this paper unravels the theories of behavioural modification. These theories were postulated by social psychologies to assess some fundamental question on individual(s) behavioural modification in a given environment, and at a given time. We adopted these theories as a paradigm for understanding because it clearly present's a case, on the fundamental factors affecting the students' academic performance in university of Jos. The paper adopted the social learning theory, theory of reasoned action and theory of planned behaviour to bring to limelight the theoretical knowledge of the subject matter. Thus, the significance of adopting the behaviour modification theory is to analyse critically the systematic approach to understanding the changing nature of human behaviour in a given environment and at a given time and period. In a quick summary, the social learning theory stated that by observing the behaviour of others, people assimilate and imitate that behaviour. The reasoned action theory assumes that intention is an 
important factor in determining behaviour and behavioural change. While the theory of planned behaviours emphasises the role of intention in behaviour performance but is intended to cover cases in which a person is not in control of all factors affecting the actual performance of behaviour. Details of this would be discuss in full subsequently. The fundamental idea behind this work is to examine the importance of education to the individual and the nation at large. And also evaluates the danger of social vices on students' lives and academic performance as well as the entire nation.

\section{A Brief History of University of Jos}

University of Jos was established with the vision of being an innovative institution with great interaction between 'town and gown'. Today, the university still carries a high responsibility of fashioning tastes and attitudes of the future. The University is committed to providing education that is globally competitive and relevant to the needs of today's employer and the developing challenges of Nigeria and beyond. ${ }^{1}$ University of Jos started as a Campus of the University of Ibadan in November, 1971, with the appointment of Professor E. A. Ayandele as its first Acting Principal. Its first home was the present Township campus of the University which was located along Murtala Mohammed way, Jos. Its first students admitted in January, 1972 were pre-degree students. ${ }^{2}$ Degree courses in Arts were introduced in October 1973 and in Science and Education the following year. The same year, the Bauchi Road Campus which then accommodated only the Faculties of Natural, environmental, Medical Sciences and Education was acquired. In October 1975, the then Military Government announced the establishment of seven new Universities and University Colleges including the University of Jos. Classes began at the newly reorganized University of Jos in October 1976 with 575 students spreading over the existing four faculties of Arts and Social Sciences, Education, Natural Sciences and Medical Sciences. Post-graduate programs were added in 1977. By 1978 Faculties of Law and Environmental Sciences were established and the Faculties of Arts and Social Sciences were separated. ${ }^{3}$ Professor Gilbert Onuaguluchi was appointed its first Vice- Chancellor and he was in office from October 1975 - 1978. He was succeeded by Professor Emmanuel U. Emovon from 1 st October 1978 1985. Professor Ochapa C. Onazi succeeded Professor Emovon. Professor Onazi served from 1 st October 1985 - 1989 as the $3^{\text {rd }}$ substantive Vice Chancellor. The 4th substantive Vice Chancellor is Professor M. Para Mallum who was in office from 1st October 1989 - 1993. Since then, the University has made enormous progress. By 1993, a new system for appointment of Vice-Chancellor in Nigerian Universities was introduced. There was therefore a delay in the appointment of a new Vice-Chancellor in 1993. In the interim, Prof. G. O. M. Tasie acted as Vice-Chancellor from October 1993 to March 1994. Eventually, Prof. N.E. Gomwalk was appointed Vice-Chancellor of the University in April, 1994. His tenure ended in 1999. Professor M. Y. Mangvwat was appointed Ag. Vice-Chancellor from January 2000 to May 4th 2001. He was later appointed substantive Vice-Chancellor with effect from 5th May 2001. After him, Professor Sonni Tyoden was Vice Chancellor from June 12, 2006 to June 11, 2011. He was the 7th substantive Vice- Chancellor of the university. The 8th substantive Vice-Chancellor of the University was Professor Hayward Babale Mafuyai from June 23, 2011 to June 22, 2016. The current and 9th substantive Vice-Chancellor is Professor Seddi Sebastian Maimako who assumed duty on the 23rd of June 2016.4 For easy understanding the summary of vice-chancellors and the duration of year in office are illustrated below.

\begin{tabular}{|c|c|c|c|c|}
\hline $\mathbf{S} / \mathbf{N}$ & Vice-Chancellors & Tenure & Duration & Year \\
\hline 1 & Professor E. A Ayandele & First Acting Principal & 4 Years & November 1971 - November 1975 \\
\hline 2 & Professor Gilbert Onuaguluchi & Full & 3 Years & October, $1975-30^{\text {th }}$ September, 1978 \\
\hline 3 & $\begin{array}{l}\text { Professor Emmanuel U. } \\
\text { Emovon }\end{array}$ & Full & 7 Years & $\begin{array}{c}\text { 1st October } 1978-30^{\text {th }} \text { September, } \\
1985\end{array}$ \\
\hline 4 & Professor Onazi served from & Full & 4 Years & $\begin{array}{c}\text { 1st October } 1985-30^{\text {th }} \text { September } \\
1989\end{array}$ \\
\hline 5 & Professor M. Para Mallum & Full & 4 Years & $\begin{array}{c}\text { 1st October } 1989-30^{\text {th }} \text { September } \\
1993\end{array}$ \\
\hline 6 & Prof. G. O. M. Tasie & Interim/acting & 1 Year & October 1993 - March 1994 \\
\hline 7 & Prof. N.E. Gomwalk & Full & 5 Years & April 1994 - December 1999 \\
\hline 8 & Professor M. Y. Mangvwat & Acting & 1 Year & January $2000-$ May $4^{\text {th }} 2001$ \\
\hline 9 & Professor M. Y. Mangvwat & Full & 6 Years & 5th May $2001-$ June $11^{\text {th }} 2006$ \\
\hline 10 & Professor SonniTyoden & Full & 5 Years & June $12^{\text {th }} 2006-$ June $11^{\text {th }} 2011$ \\
\hline 11 & $\begin{array}{c}\text { Professor Hayward } \\
\text { BabaleMafuyai }\end{array}$ & Full & 5 Years & June 23,2011 to June 22,2016 \\
\hline 12 & $\begin{array}{c}\text { Professor Seddi Sebastian } \\
\text { Maimako }\end{array}$ & Full & $\begin{array}{l}4 \text { Years still } \\
\text { counting. }\end{array}$ & 23rd of June 2016 to Date \\
\hline
\end{tabular}

Table 1: Breakdown of the Office of the Vice-Chancellors in University of Jos Nigeria.

Source: Information Retrieved from Wikipedia, Free Encyclopaedia and University of Jos Website, Restructured and Compiled by the Authors

\footnotetext{
1University of Jos website, http://www.unijos.edu.ng/about-us. (accessed 17th January, 2020)

2University of Jos - Wikipedia, https://en.wikipedia.org/en.wikipedia.org > wiki >

file://C:/Users/first\%20user/Downloads/his\%20of\%20unijos/University\%20of\%20Jos\%20History\%20_\%20University\%20of\%20Jos.html

${ }^{3}$ Ibid

${ }^{4}$ University of Jos History | University of Jos From Wikipedia, the free encyclopedia www.unijos.edu.ng >

file:///C:/Users/first\%20user/Downloads/his\%20of\%20unijos/University\%20of\%20Jos\%20-\%20Wikipedia.html
} 
From the extracted information and restructured details from various sources above, it clearly shows the summary of vice-chancellors, tenure, duration in office and the year of assumption and handing over. From the year of establishment in 1971, University of Jos had grown and expanded in various field of knowledge, with faculties and departments. University of Jos has 12 faculties and 91 Departments which had grown over a period of time. University of Jos is a well-organised research institution with conducive learning environment, well equipped library, laboratories, research centres, directorates, qualified lecturers and a favourable weather which encourages learning. The institution has graduated great personalities and intellectuals in Nigeria and in the diaspora. With all these features, the paper observed that the value of education is declining by the day and students desire to study is getting cold due to certain factors. Proper examination of these factors will go a long way in salvaging the endangered problem from becoming more severe in the society.

\section{Theoretical Analysis of the Subject Matter}

Behaviours Modification Theory (BMT) is adopted in this paper to explain why and how behaviours of individuals (students) change in a given place and at a given time. Behaviours of student(s) can be modified or changed, from a state of negative situation to a state of positive one or vice versa. ${ }^{5}$ Behaviour modification theory is a systematic approach to understanding the changing nature of human behaviour. Students learned new behaviours in campus because they feel they are the boss of themselves, they observed and imitate those ahead of them or exhibit what the conceived to be the normal and acceptable life in campus. They learn new behaviours and values that put them in a difficult position to perform well in their academic pursuit. Some had a preconceived idea that university is a place to catch fund, forgetting the actual aim that brought them. Stella in response to the above observed that most new students in campus feel that university of Jos is an arena for enjoyment and socialization. They learned dirty habit, in the name of boy/girl relationship, just to be accepted and not to feel left out.6Yang and Chau buttress further that the first year of undergraduate education is a stage in which students establish new habits, values, behaviours and relationships that would profoundly influence their development, failure and success at university. ${ }^{7}$ The number of years a student spends in the university is a critical transitional phase in which student become integrated into community. The behaviour he/she graduates with is a reflexion of the habit he/she learned, whether good or bad. In order to understand this argument, the theories of behaviours modification would be adopted and these theories are mostly propounded by social psychologies. For the purpose of this paper: Social learning theory, Theory of reasoned action, and Theory of planned behaviour were adopted. The paper adopts these theories to explain the reasons why the performance of students in University of Jos is diminishing by the day.

\subsection{Social Learning Theory (SLT)}

This theory was propounded by Albert Bandura in 1977. This theory is based on the idea that we learn from our interactions with others in a social context. Separately, by observing the behaviours of others, people develop similar behaviours. After observing the behaviour of others, people assimilate and imitate that behaviour.SLT posits that people learn from one another, via: Observation; Imitation; and Modelling. ${ }^{8}$ For that reason, Bandura argued that people can learn new information and behaviours by watching other people. ${ }^{9}$ Where he believed that behaviour and the environment affects each other. He described it as the reciprocal relationship between social characteristics of the environment, how they are perceived by individuals, and how motivated and able a person is to reproduce behaviours they see happening around them. SLT also known as observational learning, occurs when an observer's behaviour changes after viewing the behaviour of a model. ${ }^{10}$ An observer's behaviour can be affected by the positive or negative display of behaviour seen. In this theory behaviours and the environment play a fundamental role in behavioural change. An individual's environment and thoughts affect their behaviours, likewise, the environment affects the way the individual thinks or feels. Arguing in line with Bandura, other scholars also propounded the natural evil theory (Sigmund Freud, Psychoanalytic theory), natural goodness theory (Jean Jacques Rousseau) and evolving man theory (Charles Darwin's theory of evolution), all viewed the environment as a major factor that shapes the thinking and behaviours of man either negatively or positively. Lannap buttressed in agreement with the above idealism by stating that the environment makes up the platform of learning where wanted and unwanted behavioural traits are formed with the individual. Many of the bad behaviours and attitudes found among people that need behaviour change are traceable to the environment or society the individuals find themselves. ${ }^{11} \mathrm{~A}$ quick emphasis on the negative aspect of the subject matter, most freshmen admitted into the campus (University of Jos) became socially involved in negative social life styles which they perceived the environment has to offer.12Jessica in an interview argued that some blamed their academic failure on the environment rather than themselves. Most often students start off at the wrong foot, they become busy fitting in, the social environment and the environment in turn

${ }^{5}$ A. L. Lannap, Basic Issues in Guidance and Counselling, (Zaria Road Jos, Published by Mono Expression LTD, 2012 ), 51.

'Interview with, Emeka Stella, 26 Years, Student, Village Hostel, 28 ${ }^{\text {th }}$ November, 2019

${ }^{7}$ Min Yang \& Albert Wai Lap Chau, 'Social involvement and development as a response to the campus student culture'Asia Pacific Educ. Rev. 12, 393-402 (2011) doi:10.1007/s12564-011-9149-x, 24 February 2011

${ }^{8}$ RaziehTadayonNabavi 'Bandura's Social Learning Theory \& Social Cognitive Learning Theory', (University of Science and Culture Tehran, Iran, 2012) Available at: www.researchgate.net > publication > 267750204_Bandura's_Social_(accessed 18th January, 2020$), 5$.

9Ibid, 6

${ }^{10}$ Edinyang, Sunday David, 'The Significance of Social Learning Theories in the Teaching of Social Studies Education', International Journal of Sociology and Anthropology Research, Vol. 2, No.1, pp.40-45, August 2016, Published by European Centre for research Training and Development UK (www.eajournals.org) ISSN: ISSN 2059-1209, ISSN: ISSN 2059-1217, (accessed 17th January, 2020), 40

${ }^{11}$ Lannap, Basic Issues in Guidance....52

${ }^{12}$ Interview with, Joseph Ibrahim, 33 Years, Student, Abuja Hostel, 28th November, 2019 
shapes their thinking, distancing them away from their studies, before the realised, they have hit the rock. ${ }^{13}$ The idea of campus socialization to a larger extend have created more harm than good in the performance of students.

\subsection{Theory of Reasoned Action (TRA)}

This theory was postulated by Martin Fishbein and Icek Ajzen in the late 1970s. The theory assumes that intention is an important factor in determining behaviour and behavioural change. According to Fishbein and Ajzen, intentions develop from an individual's perception of behaviour as positive or negative together with the individual's impression of the way their society perceives the same behaviour. Thus, personal attitude and social pressure shape intention, which is essential to performance of a behaviour and consequently behavioural change. ${ }^{14}$ Hagger also argued that the central construct of the theory is intention. Intention reflects the extent to which an individual is likely to plan to do, and invest effort in pursuing, a given behaviour. Intention is conceptualized as a function of two belief-based constructs: attitudes and subjective norms. Attitudes are positive or negative evaluations of performing the behaviour in future, while subjective norms reflect beliefs that significant others would want them to perform the behaviour. ${ }^{15}$ Quynh et al, further expand and support Hagger's analysis by evaluating that within the TRA framework, behavioural intention, which largely determines actual behaviour, is an additive function of two variables: attitudes (positive or negative evaluation of performing a behaviour), and subjective norms (perceived influences that others may have). In general, an increase in attitude and subjective norms leads to a stronger intention to perform the behaviour. ${ }^{16}$

Attitude is an individual's favourable or unfavourable feeling about performing a specific behaviour. An individual will intend to perform certain behaviour when he or she evaluates it positively. Attitudes are determined by an individual's belief about the consequences of performing the behaviour (behavioural beliefs), weighted by his/her evaluation of these consequences (outcome evaluations). Thus, attitude is an individual's salient belief as to whether the outcome of his or her behaviour will be positive or negative. ${ }^{17}$

Subjective norms are assumed to be a function of beliefs that individuals approve or disapprove of the behaviour. Beliefs that underlie subjective norms are normative beliefs. Normative social influence is defined by the influence of other people which leads us to conform in order to be liked and accepted by them. Although an action may not be accepted or approved by an individual, normative social influence places pressure on an individual to comply with the group's social norms. Normative social influence has been shown to impose a high persuasive influence on individuals.18Intention is a very strong driving force of behavioural change in the university. Personal attitude and social pressure shape intention. To acknowledge the strong pressure attach to intention in performing a giving behaviours, Fashola observed that even secondary schools located around the university vicinity or where university students are dominant in that areas are at risk of joining cult groups. ${ }^{19}$ Most of the students observed, and tried to imitate the behaviour of those cultists around their vicinity, because they see them as role models. Their notion to join the university is to belong to a secret group. ${ }^{20}$ Janet noted that despite the dangers and disadvantages involved in joining this cult group, on daily basis, student still join them. They long to join because of popularity, quest for power, dominance, and search for protection and to perfect their bad habit etc. ${ }^{21}$ Others joined these groups as a result of social pressure. Many who accidentally joined the cult groups suffer persuasion from their friends who are already members. They innocent ones are forcefully threatened and conscripted into it, because of the influential position of their parent in the society. Cultists are always absent in lectures and they perform poorly in academic exercise.

\subsection{Theory of Planned Behaviour (TPB)}

The Theory of Planned Behaviour is an extension of the Theory of Reasoned Action. In 1985, Icek Ajzen expanded upon the theory of reasoned action, formulating the theory of planned behaviour, which also emphasises the role of intention in behaviour performance but uses intended to cover cases in which a person is not in control of all factors, affecting the actual performance of behaviour. ${ }^{22}$ Zhang held the view that human behaviour is more often affected by the factors of external and objective circumstance rather than completely controlled by the individual will. ${ }^{23}$ Their influence on specific actions in specific situations is greatly attenuated by the presence of other, more immediate factors. ${ }^{24} \mathrm{As}$ are emphasize on this by revealing that, the first construct of the theory is behavioural intention, which is the motivational factors that influence behaviour. The stronger the intention to engage in a given behaviour, the more likely it is to perform

${ }^{13}$ Interview with, Jessica James, 24 Years. Student, Naraguta Hostel, 28 ${ }^{\text {th }}$ November, 2019

${ }^{14}$ Behavioural change theories, Wikipedia, the free encyclopedia,

file://C:/Users/first\%20user/Downloads/social\%20theory/Behavioural\%20change\%20theories\%20\%20Wikipedia.html

${ }^{15}$ Martin S. Hagger, 'The Reasoned Action Approach and the Theories of Reasoned Action and Planned Behaviour', In D. S. Dunn (Ed.), Oxford Bibliographies in Psychology.(New York, NY: Oxford UniversityPress). doi: 10.1093/0BO/9780199828340-0240 (accessed 17th January, 2020), 2

${ }^{16}$ QuynhAnh Nguyen,et'al, 'Theory of Reasoned Action as a Framework forCommunicating Climate Risk: A Case Study of Schoolchildren in the Mekong Delta in Vietnam'Journal of Sustainability, 2018 Received: 21 May 2018; Accepted: 12 June 2018; Published: 14 June 2018 www.mdpi.com > pdf. 2

${ }^{17}$ Ibid

18 Ibid

${ }^{19}$ Interview with, Nathaniel Fashola, 44 Years, Teacher, Bauchi Ring Road Jos, 9 ${ }^{\text {th }}$ December, 2019

${ }^{20}$ Interview with, BulusGyang, 64 Years, Tired Civil Servant, Army Engineer, 18 ${ }^{\text {th }}$ December, 2019

${ }^{21}$ Interview with, Francis Janet, 44 Years, Trader, FarinGada, $22^{\text {nd }}$ December, 2019

${ }^{22}$ Behavioural change theories, Wikipedia, the free encyclopedia,

file://C:/Users/first\%20user/Downloads/social\%20theory/Behavioural\%20change\%20theories\%20\%20Wikipedia.html

${ }^{23}$ Ke Zhang, 'Theory of Planned Behaviour: Origins, Development and Future Direction', International Journal of Humanities and Social Science Invention (IJHSSI), ISSN (Online): 2319 - 7722, ISSN (Print): 2319 - 7714www.ijhssi.org ||Volume 7 Issue 05 Ver. IV ||May. 2018 || PP.76-83, www.ijhssi.org, 76

${ }^{24}$ IcekAjzen, The Theory of Planned Behaviour, (University of Massachusetts at Amherst, Copyright by Academic Press. Inc, 1991) Available at: www.researchgate.net > 263998069Thetheoryofplannedbehavior, 181 
that behaviour. The second construct is attitude towards the behaviour which is the extent to which a person has a favourable or unfavourable appraisal of a given behaviour. Attitude consists of behavioural beliefs and outcome evaluations. Subjective norm is the third construct which is a social pressure to perform or not to perform a given behaviour. Combination of normative beliefs and motivation to comply constitute subjective norm. Perceived behavioural control also plays a key role in the TPB and it refers to people's perception of the ease or difficulty of performing the behaviour of interest. 25

To crown the TPB, three concepts need to be put into consideration, intention, attitude and subjective norm. These are strong words that give room for external locust of control. Most young girls in campus unconsciously have this burning desire to look beautiful, to be liked and to be loved, to get approval from significant other. They have sex with significant others they met in clubs, parties and any social gathering and it becomes an attitude. This attitude now becomes habits which metamorphose in to campus prostitution. Becky in reaction to this revealed that many female students are secretly turning into sex workers to fund basic living costs while at campus. They have this inner conviction that what they are doing is bad, but they cannot just control it. When they are advice to stop, they blamed it on the poor financial status of the country and also their family. ${ }^{26}$ Campus prostitution affects their performance in school. They often times, blame their poor academic performance on the lecturers, the poor nature of learning facilities or their friends, not their activities. Thus, these theories are considered applicable in understanding the factors influencing students' academic failure in university of Jos.

\section{Factors Influencing Academic Failure in University of Jos}

\subsection{Social Media}

The impact of social media on students' performance is an important issue that has caught both educators' and practitioners', particularly on the increasing amount of time students spend online Facebooking, twittering, WhatsApp, Instagram, 2go, etc. In line with the effect of social media on student performance, Peter observed that undergraduates' students spend more time on Facebook, Twitter and other social media through smartphones and android phones that are now in abundance among university students. Many students cannot go for two-three hours even minutes, without checking and updating their profiles on these social networks even at the detriment of other activities such as educational and career pursuit. ${ }^{27}$ Carter averred that freshmen and women spend upwards of 12 hours a day using some form of social media. Social networking and watching un-educative movies are most negatively associated with poor academic performance among the students. ${ }^{28}$ Olubiyi noted that these days' students are so engrossed in the social media that they are almost 24 hours online. Even in classrooms and lecture theatres, it has been observed that some students are always busy pinging, 2going or Facebooking, while lectures are going on. Times that ought to be channelled towards learning, academic research and innovation have been crushed by the passion for meeting new friends online, and most times busy discussing trivial issues. Hence, students' academics suffer setback as a result of distraction from the social media. ${ }^{29}$ Bello, observes that if the dangerous trend of social media 'obsession' is left unchecked it could further affect an already collapsing education system in Nigeria. ${ }^{30}$

\subsection{Campus Marriage and Prostitution}

The growing rate of campus prostitution in Nigeria's tertiary institutions is raising a serious concern among Nigerians. The high level of immorality is alarming, which calls for a sober reflection. Morality is losing its essence, which is as a result of the loss of value system which remains the foundation for societal renewal of sane communities. ${ }^{31}$ Campus marriage and prostitution is very detrimental to the performance of students in university of Jos. Most students who engaged in campus marriage and prostitution either joined the train voluntary or were influenced by their peers forcefully or through manipulative means to start moving around bars and meeting men. Some stay alone road side; some are connected with politicians through pins, while others lived with their boyfriends in the name of 'campus marriage'. The excitement from secret and night life and freedom from parents attracts students to engage in these behaviours. Interview with Mercy, Jane, Rosaline, Dorothy, and Ann confirmed that, the reason why students in University of Jos indulge in campus marriage and prostitution escapades are: to compensate for past emotional neglect from significant others, utilizing sexual expressions to feel like they are needed, desired and useful. They also indulged in these dirty lives to get good grades from lecturers, attention from the opposite sex, financial assistant, security and to oppress their fellow girlfriends. ${ }^{32}$ nnwubiko and Okonkwo rightly observed that politicians, especially law makers, business men and major

${ }^{25}$ Matthew Asare, 'Using the Theory of Planned Behaviour to Determine the Condom Use Behaviour Among College Students' Am J Health Stud. 2015; 30(1): 43-50. PMCID: PMC4621079,

Retrieved from www.ncbi.nlm.nih.gov > pmc > articles > PMC4621079, (accessed 18 ${ }^{\text {th }}$ January, 2020), 44

${ }^{26}$ Interview with, Momoh Becky, 26 Years, Student, Tina Junction, 28 ${ }^{\text {th }}$ November, 2019

${ }^{27}$ Osharive Peter, 'Social Media and Academic Performance of Students In University of Lagos' (Bachelor Of Arts B.A(Ed) Degree In Educational Administration, University of Lagos, 2015), 35

${ }^{28}$ Denny Carter, Social Media Has Negative Impact on Academic Performance, e-campus news, www.ecampusnews.com > 2013/04/17 > research-socialmedia-has-ne. (accessed 20 th January, 2020)

${ }^{29}$ Olubiyi'S.(2012),social media and Nigeria Youth burden. http://bluepringng.com/2012/12/social-media-andnigerian-youth-burdenretrieved $21 / 05 / 2013$.

${ }^{30}$ Bello, cited in Osharive Peter, 'Social Media and Academic Performance of Students In University of Lagos' (Bachelor Of Arts B.A(Ed) Degree In Educational Administration, University of Lagos, 2015), 26

${ }^{31}$ Emmanuel Onwubiko\& Sylvia N. Okonkwo, NIGERIA: IS CAMPUS PROSTITUTION A MENACE? Thewillnigeria.com,Retrieved from www.swiftnews.com.ng > 2017/05/01 > prostitution-causes-effects-preventi., January $26^{\text {th }} 2013.3$

${ }^{32}$ Focus Group Discussion with Mercy, Jane, Rosaline, Dorothy, and Ann, StudentsUniversity of Jos, Off-Campus Bauchi Ring Road Jos, 7 th December, 2019. 
office holders are the ones who patronize these female students even as government offices now have departments of protocol whereby female students of tertiary institutions are hired for high profile political office holders at the expense of the tax payers. Group discussion with James, Stanley, Mike, Jennifer, Arin, Kafas, Lynda, Emmanuella, Finka and Grace, pointed out that a visit to the female hostels at night, one would be amazed at the kind of flashes and expensive cars that come to pick these young undergraduates for one nocturnal function or jamboree party. ${ }^{33}$ With the campus prostitution female students now belong to cabals of prostitutes whereby rich clients are supplied with enough quantity of female students at the touch of a button. ${ }^{34}$ Davis noted that this trend become somewhat significant and a norm among university of Jos students who strive to excel in what could be described as an increasingly competitive culture on campus. ${ }^{35}$

\subsection{Social Activities}

Students who reside on campus or off campus without family members face greater risk of experiencing social activities in and outside the university than those who are staying with their families. ${ }^{36}$ Social activities on campus are negatively associated with grades and too much of it leads to poor academic performance. The strong desire to socialize affects students' performances due to much attention to entertainment and social activities. Abiola opined that bad influence in the process of partying with friends, students can get engaged with bad peers and this may lead them into bad habits like smoking, alcoholism, drugs, pre-marital sex, crimes amongst other bad acts. Too much engagement in social activities leads to absence from lectures. Students can get carried away if proper attention is not paid to the social activities on campus and this could lead to absence from lectures, test and exam. ${ }^{37}$

\subsection{Cultism}

In retrospect, the educational institutions in Nigeria were not associated with secret cults until 1952 when Wole Soyinka and six others (Olumuyiwa Awe, Ralph Opara, TunjiTubi, Daign Imokhuede, Pius Olegbe and Olu Agunloye) formed the Seadogs confraternity (a.k.a Pyrates). The idealism behind the formation of the confraternity was for both patriotic and altruistic as it was not imagined as a secret cult. The main objectives of the seadogs were: to fight nonviolently but intellectually and effectively against the imposition of foreign conventions; to revive the age of chivalry; and to find a lasting solution to the problems of tribalism and elitism..$^{38}$ Today, cult groups in university of Jos carry out many anti-social activities on campuses. ${ }^{39}$ Despite the fact that all manners of evil (such as examination malpractice, rape, robbery, arson, maiming, murder, killing, intimidation of fellow students and lecturers for good grades, love (girlfriend), clashes of rival cult group among others) are detrimental to the individual(s) academic pursuits and the university, some students still find it fashionable to engage in it for different reasons. ${ }^{40}$ Reasons such as: search for responsibility, search for satisfaction of ones aspirations and needs, search for security, search for social identity, search to intimidate others, search for protection and host of others, are the reasons why student engage in cultism. ${ }^{41}$ Most cultists end up not completing their academic programmes. Today, school authorities in a bid to curb the rate of cultism and its activities, have adopted strict penalties for it which include expulsion of students involved irrespective of the academic level they are. This law has terminated the education of some students involved in cultism. Some other students involved in cultism, fail to make an average cumulative point in their examinations because of their lack of seriousness towards their studies. In severe cases, they are asked to quit school or drop out due to frustration. ${ }^{42} \mathrm{All}$ these are because cultism is a big distraction to academic's success.

\subsection{Substance Abuse}

The constant abuse of substance among students in university of Jos has become a thing of great concern to parents, university authority and the governments. Substance abuse is a major public health problem all over the world. The use and abuse of substance by university students have become one of the most disturbing health related phenomena in Nigeria and other parts of the world. ${ }^{43}$ Several students of university of Jos experience mental health problem, either temporarily or for a long period of time. Some become insane, maladjusted to school situations and eventually drop out of the university. Ruth observed that students who abused substances typically do more poorly in academic. ${ }^{44}$ Alcohol and drug consumption may have some detrimental effects on pupils' cognitive abilities, for instance, by decreasing their ability to concentrate. Concerning the indirect channels, drug and alcohol consumption may for instance be responsible for

\footnotetext{
${ }^{33}$ Focus Group Discussion with, James, Stanley, Mike, Jennifer, Arin, Kafas, Lynda, Emmanuella, Finka and Grace, University of Jos Permanent Site, $22^{\text {nd }}$ November, 2019

${ }^{34}$ Onwubiko\& Sylvia N. Okonkwo NIGERIA: IS...2

${ }^{35}$ Kingsley Davies, Theories of Prostitution, (Oxford University Press, 1917), 7

${ }^{36}$ Interview with, Dorcas Jang, 30 Years, Student, ECWA Staff, 13 ${ }^{\text {th }}$ January, 2020

${ }^{37}$ Kareem Abiola, LIFEGIST its dynamic,educational,interesting,entertaining,....whoooooow its lifegist ...lets get it started\#wink\# be happy. thespians2011.wordpress.com > 2013/06/19 > social-life-in-campus, (accessed 20 $0^{\text {th }}, 2010$ )

${ }^{38}$ I. A. Ajayi, Haastrup T. Ekundayo and F. M. Osalusi, 'Menace of Cultism in Nigerian Tertiary Institutions: The Way Out', Anthropologist, 12(3): 155-160 (2010), Available at www.krepublishers.com > T-Anth > Anth-12-3-155-10-629-Ajayi-I-A-Tt (accessed 20th January, 2020), 155

${ }^{39}$ Ibid, 156

${ }^{40}$ Abdulhafeez T. Oyewole, 'Cultism, Why, Effects and How To Curb the Menace in Ourtertiary Institutions' academia.com, www.academia.edu , CULTISM_WHY_EFFECTS_AND_HOW_TO_C... (accessed 23 ${ }^{\text {rd }}$ January, 2020), 2

${ }^{41}$ Ivor Ogidefa, An educationist, in his article 'Cultism in Educational institutions in Nigeria: causes, possible

solutions and counseling implications' published in 2008. Cited in Abdulhafeez T. Oyewole, 'Cultism, Why, Effects and How To Curb the Menace in Our tertiary Institutions' academia.com, www.academia.edu > Cultism_Why_Effects_And_How_To_C... (accessed 23rd January, 2020), 2

4210 Effects Of Cultism On Nigerian Youths, infoguidenigeria.com > Security

43 NDLEA, (1997) Drug date collection and research, Lagos: Drug Demand and Reduction Unit National Drug

Law Enforcement Agency

${ }^{44}$ Interview with, Ruth Chundungyusuf, 68 Years, Tired Nurse, Rock Haven, 20th January, 2020
} 
shifting individuals' resources away from their academic pursuits. Additionally, it may undermine students' progress by making them less likely to attend classes or keep up with their studies. ${ }^{45}$ Chikweru and Onyinyech posited that substance abuse have immense effect on the academic performance of the students. Drug and alcohol abuse alter the brain chemistry and interferes with the students' ability to make decisions and concentrate in their academic work. It results in impairment of mental activities or capacity of the students and destabilizes their body function and emotion for academic proficiency. Due to various bodily and mental diseases and problems associated with drug abuse, many students find it difficult to face their academic work. Drug and alcohol abuse have made students less serious and concern about their academics as they stay away from classes and lectures. substance abuse debilitates thestrength and willpower of the students to study their books and engage in other academic activities, which has led to their poor academic performance. ${ }^{46}$ Finally, psychologists argue that heavy drinking may lower individuals' expectations about their academic performance. This effect could be driven by a shift in students' peers when they engage in abusive alcohol and drugs consumption. ${ }^{47}$

\subsection{Abusive Relationship}

Boy-girl relationships are expressions of adolescents' deep and strong emotional desires towards the opposite gender. Abusive relationship is one of the dangerous factors influencing students' academic performance negatively. Poor academic performance has been associated with the emotional and cognitive impact of boy-girl relationships among university students. ${ }^{48}$ Most relationships between students in university are characterised by childish behaviours and too much of begging culture and less of seriousness of taking each other as potential marriage partners. Many young people end up feeling wasted by being in relationship that is not worth building, but that was best at swallowing their invaluable time, which they could have used to pursue other critical activities, which in long run could aid their future prosperity academically. ${ }^{49}$ Most student have adopted 'come-we-stay' arrangement while others have adopted the culture of striving to satisfy their greedy girlfriends materially, financially, inviting them to join them in eating food from big hotels that is cost, just to impress them. Some guys end up buying expensive things for their perceived girlfriend, but in reality, does not reflect critically on the commitment of the girl to the relationship. ${ }^{50}$ Unfortunately, most campus boys take their girls for granted till the girl tell the boy it's over. Most students before going to colleges do not understand the principles of a healthy relationship and how boys / men, girls / ladies of this $21^{\text {st }}$ century behave and think. These end in fake relationships, end committing suicide or lead self-pity life characterised by low self-esteem and lady phobia or guy phobia, which would eventually lead to poor academic performance. ${ }^{51}$

\subsection{Laziness to Study}

The effect of laziness in academic pursuit leads to poor performance on tests, resulting in poor grades; being lazy will cause students test scores to fall and ultimately fail.52There is no exact answer to the question why university students are lazy. It is proven fact that in the first reading, some may be able to understand moderately, a few may not be able to understand anything, which completely depends on the readers strength of the language used to communicate the subject. Hence, to understand the subject clearly one must repeatedly read the lessons few times in an extensive manner then followed by some intensive reading. So, if one is lazy to read the lessons it is highly impossible to do well in academics. ${ }^{53}$ Procrastination and laziness to study always lead to poor academic performance. Kapoor clearly stated that the biggest attribute of academic laziness is that students do not understand its ill effects on the right time, and afterwards it only leaves them in regret. 54

\section{Importance of Education and Future of the Student(S) and the Nation}

Everyone deserves to be educated and education has to be accessible to all.55 Education is a vital investment for human and economic development for the nation and is influenced by the environment within which it exists. We are living in an inquiring and innovation-oriented society. Rapidly social changes are creating uncertainty and complexity in the society. To prepare the student to cope with the present situation, the student needs to develop analytical and critical thinking, skill and attitude that would make them more flexible and innovative to deal with uncertainty and crises at

\footnotetext{
${ }^{45}$ MuritalaIsholaAkanbiet'al, 'Impact of Substance Abuse on Academic Performance among Adolescent Students of Colleges of Education in Kwara State, Nigeria'Journal of Education and Practice, www.iiste.org ISSN 2222-1735 (Paper) ISSN 2222-288X (Online) Vol.6, No.28, 2015, (accessed 20th January, 2020), 108

${ }^{46}$ Amadi, Eric Chikweru and Akpelu, Gift Onyinyech, 'Drug Abuse and Academic Performance of Secondary School Students in Emohua Local Government Area of Rivers State’ International Journal of Innovative Psychology \& Social Development, 6(1):21-26, Jan.-Mar., ISSN: 2467-8546 (SEAHI PUBLICATIONS, 2018) www.seahipaj.org (accessed 20 th January, 2020), 24

${ }^{47}$ Akanbi, Augustina, Bahago, Muritala, Ajiboye, 'Impact of Substance Abuse, 109

${ }^{48}$ BundiMarete, Eze Joy Chiamaka, Monica Gitonga and Eric Mwenda, 'Assessment of the Impact of Boy-Girl Relationships on Academic Performance Among Public Secondary School Students In Imenti North Sub-County, Meru Kenya'Ijrdo - Journal Of Educational Research,(ISSN: 2456-2947),VOL. 3 NO. 8 (2018)Retrieved from www.ijrdo.org > index.php > article > view (accessed $20^{\text {th }}$ January, 2020)

${ }^{49}$ AbdihakimBinu, The Fat Lies of Campus Boys and Relationships, Campus Vibe U Reports,www.standardmedia.co.ke > Home > Campus Vibe

50 Ibid

51 Ibid

52 The effects of being lazy or uninterested in school, www.researchgate.net >www.standardmedia.co.ke > Home > Campus Vibe publication > 5200575_Lazy_Students_A_Stud...

53 www.bartleby.com > essay > Effect-of-laziness-to-academic-performa...

${ }^{54}$ ArchanaKapoor, 'The Ill Effects of Laziness', www.indiastudychannel.com (accessed 6th February, 2020)

${ }^{55}$ Vijay K Sharma, 'Importance of education in life' Available at; www.studyread.com > Education (accessed 20 ${ }^{\text {th }}$ January, 2020)
} 
national and global level.56Malcolm X noted that, education is the passport to the future, for tomorrow belongs to those who prepare for it today. Education is very important for an individual's success in life. It can give a big impact on human opportunity in continuing their life quality. Education is generally seen as the foundation of society which brings economic wealth, social prosperity and political stability.

Secondly, economic and social status depends on education obtained by individual since education contributes to individual capability in managing quality of life. ${ }^{57}$ It can help individual to avoid poverty, build up harmony and democracy society. Education gives power to the individuals to voice out their views, expose them to real potential, lead them to become a better person and widen their views in certain area.58Vashisth rightly pointed out that economic necessities make technical and professional education very important to fully utilize the natural resources of the country. This gives boost to employment, GDP, economic growth and development. ${ }^{99}$ The ultimate aim of education as well as nations is to create the new man, the supra mental earth, where truth reigns and there is no contradiction between individual freedom and growth, social and national integration, harmony and welfare. Education for nation building should be a synthesis ofuniversal humanism, scientific curiosity and a knowledge of the vast, the supreme, the spiritual, the subtle, through whom everything evolves, gets sustenance and meaning.60

In a similar fashion, education gives meaning to individual(s) and the nation as a whole. The presence of social ills in the campus (University of Jos) hinders the individual and the nation in attaining it full potentials. Negative socialization is a diversion of student academic success or performance. Today, students only read to pass examination and not to gain knowledge. They spend most of their time chasing after un-academic pursuits that steal away their time. Instead of reading students prefer to waste their time on social media, going to night clubs and partying all day long, abusing substances to make them high, prostitution to get money and joining cult groups to seek for prestige and to intimidate others. All these social ills are very dangerous to the lives of the students and the nation at large. For example, one could get killed in gang violence, a student could contact STD in the process of prostituting, abusing substances would lead to mental disorder and engaging in social media leads to time wastage and subsequently poor academic performance. It is very important to note here that examination malpractice is anti-education. Students waste their time on valueless things, at the end of the day, they indulge in examination malpractice as their last resolve; they do so because they are not prepared for the examination. This has a lasting effect on the intellectual capability of the student and socio-economic and political structure of Nigeria. One would observe that such student who indulges in this kind of anti-educational activity finds it very difficult to compete with his contemporaries in the labour market because knowledge was not impacted but was only acquired to pass through the university by dubious means. The effect of this is that, the work force of the country would be very weak intellectually and skilfully. If nothing is done, it would lead to structural and institutional decay.

In line with the above analysis, Udim, Abubakar and Essien rightly posited, that examination malpractice has a negative effect on the society, it leads to irreversible loss of credibility, has negative consequences on the individuals and institution of learning, it leads to moral decadence, brain drain and discourages hard work and encourages corruption among students. ${ }^{61}$ Akaranga and Ongong also noted that examination is not only a process of assessing the progress of students but, it also motivates and help them to know their academic strengths and weaknesses apart from providing teachers with opportunities to try new methods of teaching. But when examination is not properly conducted, the expected feedback may not be obtained. ${ }^{2}$

\section{Conclusion}

This paper had attempted to examine the theoretical factors that influenced poor academic performance among students in University of Jos. Social learning theory, theory of reason and theory of planned behaviours where adopted and used as a paradigm to bring to knowledge the salient fact about environment and intentions. The paper analysed some major factors that hinders students' academic performance in University of Jos such as social media, campus prostitution and marriage, cultism, substance abuse, laziness, examination malpractice, negative relationship among students and social activities (clubbing and partying). It is important to note that the environment is a major factor that influences academic performance of students. Students joined these social ills intentionally or were forced into it. The effect of this is poor academic performance which always has a negative effect on the student life and the nation as a whole. The paper recommends strongly that the Examination Malpractice Act 33 of 1999, be amended to incorporate that section of Degree 20 of 1984 which stated 21 years imprisonment without option of fine for any students caught in the act. This would help reduce, if not eliminate social ills in the campus.

56 The Nation News Paper, 'Role of Education In National Development', January 16, 2020.

${ }^{57}$ FazilahIdris, Zaharah Hassan ,AzizahYa'acob ,Saran Kaur Gill \& Noor AziahMohdAwal, 'The role of education in shaping youth's national identity'Journal of Procedia - Social and Behavioral Sciences, 59 ( 2012 ) 443 - 450 Available online at www.sciencedirect.com (accessed 22 nd January, 2020 ), 443

58 Ibid, 444

${ }^{59}$ SuchitraVashisth, 'Role of Education in Nation Building', IOSR Journal Of Humanities And Social Science (IOSR-JHSS) Volume 23, Issue 7 , Ver. 7 (July. 2018) PP 52-54 e-ISSN: 2279-0837, p-ISSN: 2279-0845.

www.iosrjournals.org, (accessed 20 th December,2019), 52

60 Ibid

${ }^{61}$ Davies Kelvin Udim, Umar Abubakar, and Joshua OtobongEssien, 'An Indepth Evaluation on the Issue of Examination Malpractice in Nigeria', Reseach in Pedagogy, Vol. 8, No. 2, 2018, pp 204-213, 204

${ }^{62}$ S. I Akaranga and J. J Ongong, The Phenomenon of Examination Malpractice: An Examination of Nairobi and Kenyatta University', Journal of Education and Practice, 4(18), 87-96. 


\section{References}

i. Abiola Kareem, LIFEGIST its dynamic, educational, interesting, entertaining, ....whoooooow its lifegist ...lets get it started\#wink\# be happy. thespians2011.wordpress.com > 2013/06/19 > social-life-in-campus, accessed $20^{\text {th }}, 2010$

ii. Ajayi I. A., Ekundayo T Haastrup. And Osalusi F. M., 'Menace of Cultism in Nigerian Tertiary Institutions: The Way Out', Anthropologist, 12(3): 155-160 (2010), Available at www.krepublishers.com > T-Anth > Anth-12-3155-10-629-Ajayi-I-A-Tt accessed 20th January, 2020

iii. AjzenIcek, The Theory of Planned Behaviour, University of Massachusetts at Amherst, Copyright by Academic Press. Inc, 1991, Available at: www.researchgate.net > 263998069Thetheoryofplannedbehavior

iv. Akanbi MuritalaIshola, Augustina Godwin, Theophilus Anyio Bahago, Muritala Muhammad, Ajiboye Ajiboye Stephen, 'Impact of Substance Abuse on Academic Performance among Adolescent Students of Colleges of Education in Kwara State, Nigeria'Journal of Education and Practice, www.iiste.org ISSN 2222-1735 (Paper) ISSN 2222-288X (Online) Vol.6, No.28, 2015, accessed 20th January, 2020

v. Akaranga S. I and Ongong J. J, The Phenomenon of Examination Malpractice: An Examination of Nairobi and Kenyatta University', Journal of Education and Practice, 4(18), 87-96.

vi. Asare Matthew, 'Using the Theory of Planned Behaviour to Determine the Condom Use Behaviour Among College Students' Am J Health Stud. 2015; 30(1): 43-50. PMCID: PMC4621079, Retrieved from www.ncbi.nlm.nih.gov > pmc > articles > PMC4621079, accessed 18 ${ }^{\text {th }}$ January, 2020

vii. Behavioural change theories, Wikipedia, the free encyclopedia, file://C:/Users/first\%20user/Downloads/social\%20theory/Behavioural\%20change\%20theories\%20\%20 Wikipedia.html

viii. Behavioural change theories, Wikipedia, the free encyclopedia, file://C:/Users/first\%20user/Downloads/social\%20theory/Behavioural\%20change\%20theories\%20\%20 Wikipedia.html

ix. Bello, cited in Osharive Peter, 'Social Media and Academic Performance of Students In University of Lagos' Bachelor Of Arts B.A(Ed) Degree In Educational Administration, University of Lagos, 2015

$x$. BinuAbdihakim, The Fat Lies of Campus Boys and Relationships, Campus Vibe $U$ Reports,www.standardmedia.co.ke > Home > Campus Vibe

xi. Carter Denny, Social Media Has Negative Impact on Academic Performance, e-campus news, www.ecampusnews.com > 2013/04/17 > research-social-media-has-ne. accessed 20th January, 2020

xii. ChikweruAmadi, Eric and Onyinyech Akpelu, Gift, 'Drug Abuse and Academic Performance of Secondary School Students in Emohua Local Government Area of Rivers State' International Journal of Innovative Psychology \& Social Development, 6(1):21-26, Jan.-Mar., ISSN: 2467-8546 (SEAHI PUBLICATIONS, 2018) www.seahipaj.org accessed 20th January, 2020

xiii. David Edinyang, Sunday, "The Significance of Social Learning Theories in the Teaching of Social Studies Education', International Journal of Sociology and Anthropology Research, Vol. 2, No.1, pp.40-45, August 2016, Published by European Centre for research Training and Development UK www.eajournals.org ISSN: ISSN 2059-1209, ISSN: ISSN 2059-1217, accessed 17th January, 2020

xiv. Davies Kingsley, Theories of Prostitution, Oxford University Press, 1917

xv. Effects Of Cultism On Nigerian Youths, infoguidenigeria.com > Security file://C:/Users/first\%20user/Downloads/his\%20of\%20unijos/University\%20of\%20Jos\%20History\%20_\% 20University\%20of\%20Jos.html

xvi. Focus Group Discussion with, James, Stanley, Mike, Jennifer, Arin, Kafas, Lynda, Emmanuella, Finka and Grace, University of Jos Permanent Site, 22 ${ }^{\text {nd }}$ November, 2019

xvii. Focus Group Discussion with Mercy, Jane, Rosaline, Dorothy, and Ann, Students University of Jos, Off-Campus Bauchi Ring Road Jos, $7^{\text {th }}$ December, 2019.

xviii. Hagger Martin S., "The Reasoned Action Approach and the Theories of Reasoned Action and Planned Behaviour', In D. S. Dunn (Ed.), Oxford Bibliographies in Psychology. (New York, NY: Oxford University Press, doi: 10.1093/0B0/9780199828340-0240 accessed 17th January, 2020

xix. Idris Fazilah, Hassan Zaharah, Ya'acob Azizah , Gill Saran Kaur \& Mohd Awal Noor Aziah, 'The role of education in shaping youth's national identity' Journal of Procedia - Social and Behavioral Sciences, 59 ( 2012 ) 443 - 450 Available online at www.sciencedirect.com accessed 22nd January, 2020

xx. Interview with, Emeka Stella, 26 Years, Student, Village Hostel, 28 ${ }^{\text {th }}$ November, 2019

xxi. Interview with, Joseph Ibrahim, 33 Years, Student, Abuja Hostel, 28th November, 2019

xxii. Interview with, Jessica James, 24 Years. Student, Naraguta Hostel, 28th November, 2019

xxiii. Interview with, Nathaniel Fashola, 44 Years, Teacher, Bauchi Ring Road Jos, 9th December, 2019

xxiv. Interview with, Bulus Gyang, 64 Years, Tired Civil Servant, Army Engineer, 18 ${ }^{\text {th }}$ December, 2019

xxv. Interview with, Francis Janet, 44 Years, Trader, FarinGada, 22nd December, 2019

xxvi. Interview with, Momoh Becky, 26 Years, Student, Tina Junction, 28 ${ }^{\text {th }}$ November, 2019

xxvii. Interview with, Ruth Chundungyusuf, 68 Years, Tired Nurse, Rock Haven, 20 January, 2020

xxviii. KapoorArchana, 'The Ill Effects of Laziness', www.indiastudychannel.com accessed 6 ${ }^{\text {th }}$ February, 2020

xxix. Lannap A. L., Basic Issues in Guidance and Counselling, Zaria Road Jos, Published by Mono Expression LTD, 2012 
xxx. Marete Bundi, Chiamaka Eze Joy, Gitonga Monica and Mwenda Eric, 'Assessment of the Impact of Boy-Girl Relationships on Academic Performance Among Public Secondary School Students In Imenti North SubCounty, Meru Kenya' Ijrdo - Journal Of Educational Research, (ISSN: 2456-2947), VOL. 3 NO. 8 (2018) Retrieved from www.ijrdo.org > index.php > article > view accessed 20 $0^{\text {th }}$ January, 2020

xxxi. Nabavi Razieh Tadayon 'Bandura's Social Learning Theory \& Social Cognitive Learning Theory', (University of Science and Culture Tehran, Iran, 2012) Available at: www.researchgate.net , publication , 267750204_Bandura's_Social_accessed 18 th January, 2020

xxxii. NDLEA, Drug date collection and research, Lagos: Drug Demand and Reduction Unit National Drug Law Enforcement Agency, 1997

xxxiii. Nguyen QuynhAnh, Hens Luc, MacAlister Charlotte, Johnson Lester, Lebel Boripat, Sinh Bach Tan, Hung Manh Nguyen, The Ninh Nguyen and Louis Lebel, "Theory of Reasoned Action as a Framework for Communicating Climate Risk: A Case Study of Schoolchildren in the Mekong Delta in Vietnam' Journal of Sustainability, 2018 Received: 21 May 2018; Accepted: 12 June 2018; Published: 14 June 2018 www.mdpi.com > pdf.

xxxiv. Ogidefa Ivor, an educationist, in his article 'Cultism in Educational institutions in Nigeria: causes, possible solutions and counseling implications' published in 2008. Cited in Abdulhafeez T. Oyewole, 'Cultism, Why, Effects and How To Curb the Menace in Our tertiary Institutions' academia.com, www.academia.edu > CULTISM_WHY_EFFECTS_AND_HOW_TO_C... accessed 23rd January, 2020

xxxv. Onwubiko Emmanuel \& Okonkwo Sylvia N., NIGERIA: Is Campus Prostitution A Menace? Thewillnigeria.com, Retrieved from www.swiftnews.com.ng > 2017/05/01 > prostitution-causes-effects-preventi., January 26 th 2013.

xxxvi. Oyewole Abdulhafeez T., 'Cultism, Why, Effects and How To Curb the Menace in Our tertiary Institutions' academia.com, www.academia.edu > CULTISM_WHY_EFFECTS_AND_HOW_TO_C... accessed 23rd January, 2020

xxxvii. Sharma k. Vijay, 'Importance of education in life', Available at; www.studyread.com.education accessed 19th January, 2020

xxxviii. The effects of being lazy or uninterested in school, www.researchgate.net > www.standardmedia.co.ke > Home > Campus Vibe publication > 5200575_Lazy_Students_A_Stud...www.bartleby.com > essay > Effect-of-lazinessto-academic-performa...

xxxix. The Nation News Paper, 'Role of Education In National Development', January 16, 2020.

xl. Udim Davies Kelvin, Umar Abubakar, Joshua Otobong Essien, 'AnIndepth Evaluation on the Issue of Examination Malpractice in Nigeria', Reseach in Pedagogy, Vol. 8, No. 2, 2018, pp 204-213

xli. University of Jos - Wikipedia, https://en.wikipedia.org/en.wikipedia.org > wiki >

xlii. University of Jos History | University of Jos From Wikipedia, the free encyclopedia www.unijos.edu.ng > file://C:/Users/first\%20user/Downloads/his\%20of\%20unijos/University\%20of\%20Jos\%20-

$\% 20$ Wikipedia.html

xliii. University of Jos website, http://www.unijos.edu.ng/about-us. (accessed 17th January, 2020)

xliv. Vashisth Suchitra, 'Role of Education in Nation Building', IOSR Journal Of Humanities And Social Science (IOSR-JHSS) Volume 23, Issue 7, Ver. 7 (July. 2018) PP 52-54 e-ISSN: 2279-0837, p-ISSN: 2279-0845. www.iosrjournals.org, accessed $20^{\text {th }}$ December,2019

xlv. Yang Min \&Wai Lap Chau Albert Social involvement and development as a response to the campus student culture.Asia Pacific Educ. Rev. 12, 393-402 (2011) doi:10.1007/s12564-011-9149-x, 24 February 2011

xlvi. Zhang Ke, 'Theory of Planned Behaviour: Origins, Development and Future Direction', International Journal of Humanities and Social Science Invention (IJHSSI), ISSN (Online): 2319 - 7722, ISSN (Print): 2319 7714www.ijhssi.org ||Volume 7 Issue 05 Ver. IV ||May. 2018 || PP.76-83, www.ijhssi.org 